\title{
PROFIL ALUMNI FAKULTAS TEKNIK DAN KEJURUAN UNIVERSITAS PENDIDIKAN GANESHA DITINJAU DARI KETERSERAPANNYA DI DUNIA KERJA
}

\author{
Oleh \\ I Gede Sudirtha, I Dewa Ayu Made Budhyani \\ Jurusan Pendidikan Kesejahteraan Keluarga, FTK, UNDIKSHA
}

\begin{abstract}
ABSTRAK
Penelitian ini bertujuan untuk mengetahui dan mengkaji : 1) profil keterserapan lulusan Fakultas Teknik dan Kejuruan Undiksha di masyarakat, 2) rata-rata masa tunggu para alumni untuk memperoleh pekerjaan di masyarakat, 3) mata pelajaran apa yang diampu di sekolah, 4) rata-rata jam mengajar alumni disekolah, 5) kompetensi lulusan FTK di lapangan dan 6) penilaian/ kepuasan alumni terhadap administrasi dan fasilitas lembaga. Populasi dalam penelitian ini adalah seluruh alumni FTK Undiksha mulai tahun 2005 sampai 2011 yang berjumlah kurang lebih 780 yang tersebar di dunia usaha dan industri, serta sekolah-sekolah di kabupaten/kota di Provinsi Bali dan sekitarnya. Data dianalisis dengan teknik deskriptif dari kuisioner yang diisi dan dikembalikan oleh para alumni, yaitu sebanyak 244 eks dari 700 eks yang disebar. Hasil penelitian menunjukkan bahwa : 1) Keterserapan lulusan Fakultas Teknik dan Kejuruan Undiksha di masyarakat ditinjau dari ketersebarannya di wilayah Bali dan sekitarnya tergolong baik yang dibuktikan dengan diterimanya alumni di berbagai bidang pekerjaan yang relevan dengan kompetensinya, 2) rata-rata masa tunggu alumni untuk memperoleh pekerjaan lulusan FTK tergolong pendek, yaitu 5.6 bulan untuk alumni Pendidikan Kesejahteraan Keluarga, 5.4 bulan untuk alumni Manajemen informatika, 6.8 bulan untuk alumni Teknik elektronika, dan 3.3 bulan untuk alumni Pendidikan Teknik Informatika, 3) mata pelajaran apa yang diampu di sekolah cukup bervariasi sesuai dengan kompetensi yang dimiliki, 4) jumlah jam mengajar alumni di sekolah tergolong cukup dengan rentang 14 jam per minggu sampai 35 jam per minggu, 5) kompetensi lulusan tergolong sangat memadai, 6) penilaian/ kepuasan alumni terhadap administrasi dan fasilitas lembaga tergolong baik, namun ada sejumlah layanan dan fasilitas yang perlu ditingkatkan oleh lembaga, seperti : layanan perpustakaan, kegiatan kemahasiswaan dan layanan internet, 7) secara umum pengguna lulusan menyatakan puas terhadap kinerja/ kompetensi lulusan FTK (100\% dari 42 pengguna yang mengisi kuisioner)
\end{abstract}

Kata-kata Kunci :Profile keterserapan, Alumni, tracer

\begin{abstract}
This study aims to identify and assess : 1) absorption profile graduate of the Faculty of Engineering and Vocational Undiksha in the communit, 2) the average waiting time for alumni to get a job in the community, 3) what subjects of teaching
\end{abstract}


at the school, 4) the average of teaching hours alumni in the school, 5 ) FTK competency in the field and 6) assessment/ satisfaction administration and the alumni of the institute facilities. This research is a descriptive survey approach. The population in this study are all alumni of FTK Undiksha from 2005 to 2011, amounting to approximately 780 spread across the world of business and industry, as well as schools in the district / city in the province of Bali and beyond. Data were analyzed from the results of the questionnaires were completed and returned by the alumni of FTK as many as 244 ex 700 ex is deployed. The results showed that : 1) absorption graduated from the Faculty of Engineering and Vocational Undiksha in community as evidenced by the alumni in various fields of work relevant to the competence, 2) the average waiting period for obtaining the alumni FTK graduate jobs is short, ie 5.6 months for Education Alumni Family Welfare, 5.4 months for Informatics Management alumnus, 6.8 months for electronics Engineering alumnus, and 3.3 months for the alumni of Information Engineering Education, 3) what subjects of teaching in schools is quite varied in accordance with their competence, 4) the average of alumni in school teaching hours is quite the range of 14 hours per week to 35 hours per week, 5) as very adequate competency, 6) assessment/satisfaction administration and the alumni of the institute facilities classified as good, but there are a number of services and facilities that need to be improved by the institution, such as library services, student activities and internet services, 7) is generally the graduates expressed satisfaction on the performance/competency FTK (100\% of 42 users who fill in the questionnaire).

Keywords : Profile, alumnus, tracer

\section{PENDAHULUAN}

Studi ini juga dilatarbelakangi oleh sejumlah isu sebagai konsekuensi dari berdirinya Fakultas Teknik dan Kejuruan yang membawahi empat jurusan/ program studi yaitu : (1) Jurusan Pendidikan Kesejahteraan Keluarga (S1) berdiri tahun 1990 sampai dengan tahun 2011 telah mengasilkan lulusan 272 orang, yang telah tersebar di berbagai daerah Bali, NTB, NTT, dan sebagian di Jawa Timur. Namun demikian, hingga kini masih perlu dilakukan studi pelacakan terhadap pemakaian lulusan oleh berbagai pihak, terutama yang bertalian dengan bidang kerja dan kualitasnya dalam melaksanakan pekerjaan dengan berbagai tuntutan perkembangan jaman di tempat kerja maupun sebagai anggota masyarakat. (2) Jurusan Manajemen Informatika (D3) yang berdiri tahun tahun 1999 sampai dengan akhir tahun 2011, jurusan ini telah meluluskan kurang lebih 585 orang, dan sebagian besar telah terserap di dunia usaha dan industri, serta ada juga yang terserap sebagai pegawai negeri sipil (PNS). 
(3) Jurusan Teknik Elektronika (D3) yang berdiri tahun 2002 sampai dengan tahun 2011 Jurusan Teknik Elektro FTK UNDIKSHA sudah meluluskan 133 orang, yang telah tersebar di berbagai pelosok daerah Bali. (4) Jurusan Pendidikan Teknik Informatika yang berdiri tahun 2008 samapai dengan tahun 2011 telah memiliki lulusan 46 orang. Pelaksanaan penelususran alumni terakhir dilakuakan tahun 2008, namun demikian, sampai tahun 2011 telah banyak lulusan yang dihasilkan sehingga perlu dilakukan studi pelacakan terhadap keterserapan alumni dan perkembangan pemakaian lulusan oleh berbagai pihak, terutama yang bertalian dengan bidang kerja dan kualitasnya sebagai outcome dan yang lebih luas yaitu prestasi di tempat kerjanya. Sejauh ini, pencatatan atau dokumentasi lulusan hanya dilakukan secara tertutup yang artinya hanya ada catatan akhir dari para lulusan yang tersimpan pada file atau buku induk lulusan Fakultas Teknik dan Kejuruan. Data ini cenderung tidak terbaharui karena hanya dikelola tanpa melibatkan alumni itu sendiri sebagai sumber data. (4) Jurusan Boga Perhotelan (D3) yang berdiri tahun 2003 sampai dengan tahun 2007 Jurusan Boga Perhotelan FTK UNDIKSHA sudah meluluskan 20 orang, yang telah tersebar di berbagai pelosok daerah Bali dan sekitarnya.

Perubahan kebijakan pada tingkat makro nasional yang sangat mendasar untuk direspon oleh pihak produsen tenaga kependidikan dan para lulusan di lapangan adalah implementasi kurikulum berbasis kompetensi pada berbagai jenjang pendidikan (Dede Rosyada, 2004 : hal 45). Bagi LPTK, Kep. Mendiknas No. 232/U/2000 dan No. 045/U/2002 memberikan konsekuensi pada perubahan kurikulum di tingkat pendidikan tinggi tenaga kependidikan, sementara lulusan hasil PBM berdasarkan kurikulum lama (Content Base Curriculum Development) perlu menyesuaikan diri dengan perkembangan yang baru. Oleh sebab itu studi pelacakan dirasakan lebih mendesak dilakukan.

Fakultas Teknik dan Kejuruan Universitas Pendidikan Ganesha sebagai produsen tenaga kependidikan belum menerapkan mekanisme pengembangan program melalui implementasi lembaga pendidikan sebagai sebuah sistem sosial terbuka yang selalu siap menyerap masukan dan umpan balik dari kinerja lulusannya di lapangan. 
Di sisi lain sebagai lembaga pendidikan yang juga menjalankan mandat dalam melaksanakan program non kependidikan (D3 Manajemen Informatika, D3 Teknik Elektro, D3 Boga Perhotelan) di Fakultas Teknik dan Kejuruan, dalam konteks kemajuan dan perkembangan ilmu pengetahuan dan teknologi yang semakin pesat membawa dampak positif terhadap perkembangan dunia pendidikan. Sebagai lembaga pendidikan yang bernaung di bawah Fakultas Teknik dan Kejuruan (FTK) Undiksha, program-program non kependidikan tersebut harus berbenah diri untuk bisa mengikuti perkembangan yang terjadi dan sebagai tindak lanjutnya perlu diadakan pembaharuan dalam semua bidang guna memenuhi tuntutan kemajuan ilmu pengetahuan, teknologi, dan seni.

Belum diketahui dengan cermat dan akurat tingkat relevansi kompetensi lulusan Fakultas Teknik dan Kejuruan Universitas Pendidikan Ganesha dengan tuntutan kerja yang menjadi tugasnya sebagai tenaga kependidikan dan non kependidikan sehingga dapat digunakan sebagai umpan balik guna pengembangan kurikulum baru di Fakultas Teknik dan Kejuruan yang berbasis kompetensi. Selain itu dapat digunakan sebagai bahan pertimbangan untuk menyelenggarakan program pengabdian pada masyarakat dalam rangka hubungan masyarakat dan pelayanan purna lulus bagi para alumni. Jadi permasalah yang dikaji dalam penelitian ini dapat dirumuskan sebagai berikut. 1) Bagaimanakah profil keterserapan lulusan Fakultas Teknik dan Kejuruan Undiksha? 2) Bagaimanakah penghargaan yang diperoleh di masyarakat atau dunia kerja? 3) Bagaimana kepuasan alumni terhadap layanan yang diperoleh selama mengikuti pendidikan di almamatertnya? 4) Berapa lamakah ratarata masa tunggu para alumni untuk memperoleh pekerjaan di masyarakat? 6) Berapakah rata-rata lama studi para alumni FTK Undiksha? 7) Hambatan-hambatan apa yang dialami lulusan ketika mereka terjun di dunia kerja baik di bidang kependidikan maupun non kependidikan? 8) Masukan atau pandangan-pandangan yang bagaimanakah yang diperoleh dari alumni sebagai umpan balik terhadap penyelenggaraan pendidikan di almamaternya sebagaimana pengalaman yang telah diperoleh selama di dunia kerja? 9) Bagaimanakah kepuasan pengguna (stakeholders) terhadap lulusan FTK Undiksha? 
Pengembangan FTK sebagai bagian dari pendidikan kejuruan harus berorientasi pada demand-driven yaitu berorientasi ke pasar kerja (Sutarto,H ; 1998). Sistim deman-driven ini juga mengacu pada kompetensi. Jadi perencanaan, pelaksanaan, dan evaluasi program pendidikan kejuruan harus merupakan hasil kajian bersama antara pihak perguruan tinggi sebagai penghasil dan dunia kerja sebagai pemakai. Pendekatan kompetensi di atas, dilihat dari segi waktu, wajib bagi kalangan akademisi untuk mengevaluasi kurikulum yang digunakan minimal dalam kurun waktu lima tahun, sejalan dengan kemajuan sains dan teknologi yang terjadi secara signifikan, untuk menunjukkan tingkat relevansi dari kurikulum.

Pengembangan kelembagaan dan kurikulum di Fakultas Teknik dan Kejuruan dengan pendekatan kompetensi tidak bisa dilepaskan dari apa yang sudah ada dan dikembangkan serta yang dilaksanakan. Terkait dengan kurikulum yang telah dijalankan sebelumnya bagi mahasiswa yang telah menyelesaikan pendidikannya yang berstatus sebagai alumni dan telah bekerja di bidang kependidikan maupun non kependidikan, untuk mengukur kompetensi lulusan dapat dilakukan melalui identifikasi pernyataan alumni tentang berbagai kekurangan kompetensi yang diperolehnya semasa pendidikan dibandingkan dengan tuntutan di dunia kerja, di samping melalui analisis data dari berbagai pihak pemakai lulusan. Acuan analisis untuk pengembangan kurikulum baik yang standar maupun kurikulum konsentrasi harus mempertimbangkan secara saksama tentang efektivitas, efisiensi, fleksibilitas, dan relevansi.

\section{METODE PENELITIAN}

Subjek penelitian adalah semua alumni Jurusan Fakultas Teknik dan Kejuruan yang dimuali dari lulusan tahun 1995 sampai dengan tahun 2011, dengan lokasi tugas kerja di berbagai Kabupaten/Kota di Propinsi Bali, Jawa Timur, NTT dan NTB. Metode utama pengumpulan data yang digunakan adalah kuesioner. Data hasil penelitian dianalisis dengan teknik deskriptif.

\section{HASIL DAN PEMBAHASAN}

Profil Alumni Fakultas Teknik Dan Kejuruan.(I G Sudirtha dan I D A M Budhyani) 


\subsection{Profil Keterserapan Lulusan FTK Undiksha}

Dari penyebaran kuisioner sebanyak 700 eksemplar ke seluruh alumni diperoleh data (kuisioner yang kembali dan terisi sebanyak 244 eksemplar. Dari data yang diperoleh tersebut selanjutnya dideskripsikan profil keterserapan lulusan akan diuraikkan beberapa bagian sesuai dengan instrumen yang digunakan dan ketersediaan data yang diperoleh dari hasil penyebaran instrumen sebagai berikut.

\subsubsection{Riwayat Pekerjaan Alumni}

Dilihat dari kompetensi dan kesesuaian pekerjaan alumni FTK seharusnya mendapatkan pekerjaan atau menekuni pekerjaan yang sesuai seperti : 1) sebagai guru untuk Jurusan/Program Studi Pendidikan Kesejahteraan Keluarga dan Pendidikan Teknik Informatika, 2) sebagai teknisi di PT PLN, PT Telkom, wiraswasta, programer, dan sebagai pranata komputer untuk Jurusan Teknik Elektronika dan Manajemen Informatika.

Berdasarkan kuisioner yang disebarkan dan yang telah dikembalikan oleh alumni diketahui variasi pekerjaan yang dialami oleh para alumni FTK sebelum memperoleh pekerjaan yang sesuai dengan kualifikasi dan kompetensinya adalah sebagai berikut : 1) Karyawan hotel/ restoran (sesuai dengan kompetensi yang dimiliki yaitu dalam bidang tata boga, tata hidang), 2) karyawan garment/ butik dengan berbagai posisi, minimal sebagai kepala bagian pola/marking, dan desainer/ asisten desainer (sesuai dengan kompetensi yang dimiliki dalam bidang tata busana, marker, maupun desain, 3) pegawai bank swasta/ BUMN, 4) Bekerja di kapal pesiar/ Cruise, 5) karyawan administrasi di sekolah, 6) guru TK dan SD, 7) wiraswasta di bidang boga, 8) wiraswasta di bidang busana, 9) wiraswasta di bidang jasa komputer dan elektronika, 10) guru honorer di bidang elektro/elektronika di SMK (bagi lulusan D3 Teknik Elektro), 11) guru honorer TIK SMP, SMA/SMK (bagi lulusan M.Informatika), 12) instruktur pada perusahan multimedia atau lembaga pelatihan, 13) teknisi komputer dan jaringan, 14) web programing (jurusan Manajemen Informatika), 15) sebagai staff IT di perusahaan/ institusi pemerintah/swasta

\subsubsection{Penghargaan/ Gaji yang Diperoleh Alumni dalam Pekerjaannya}

Dari sisi penghargaan/ gaji pertama yang diperoleh alumni diketahui sangat bervariasi berkisar antara kurang dari Rp. 300.000,- sampai lebih dari Rp. 
$1.000 .000,-$ sesuai dengan variasi pekerjaan pertama dalam riwayat pekerjaan yang diperoleh.

Berikut disajikan tabel rekapitulasi penghargaan/ gaji yang pernah diperoleh alumni berdasarkan pekerjaan pertama dari masing-masing jurusan sebagai berikut.

Tabel 01. Rekapitulasi Gaji yang Diperoleh Alumni

\begin{tabular}{|l|l|l|l|l|l|l|}
\hline No & Jurusan/ Prodi & $\mathrm{n}$ & \multicolumn{4}{|l|}{ Gaji Pertama Per Bulan (dalam ribuan rupiah) } \\
\cline { 4 - 7 } & & $<300$ & $300-600$ & $600-1000$ & $>1000$ \\
\hline 1 & $\begin{array}{l}\text { Pendidikan } \\
\text { Kesejahteraan } \\
\text { Keluarga }\end{array}$ & 59 & 12 & 23 & 5 & 19 \\
\hline 2 & $\begin{array}{l}\text { Manajemen } \\
\text { informatika }\end{array}$ & 93 & 16 & 39 & 17 & 21 \\
\hline 3 & $\begin{array}{l}\text { Teknik } \\
\text { Elektronika }\end{array}$ & 56 & 14 & 9 & 16 & 17 \\
\hline 4 & $\begin{array}{l}\text { Pendidikan } \\
\text { Teknik } \\
\text { Informatika }\end{array}$ & 36 & 8 & 18 & 2 & 8 \\
\hline \multirow{2}{*}{ Total/ \% } & $\mathbf{2 4 4}$ & 50 & 89 & 40 & 65 \\
\cline { 4 - 7 } & & $\mathbf{2 0 . 4 9 \%}$ & $\mathbf{3 6 . 4 8 \%}$ & $\mathbf{1 6 . 3 9 \%}$ & $\mathbf{2 6 . 6 4 \%}$ \\
\hline
\end{tabular}

\subsubsection{Riwayat Jabatan yang Pernah Diduduki Selama Bekerja}

Beberapa jabatan yang pernah diduduki alumni selama bekerja baik sebelum diangkat sebagai guru tetap/ PNS diketahui yaitu : sebagai wakil kepala sekolah, sebagai ketua program studi di SMK, sebagai kepala bagian pola(untuk bidang tata busana), sebagai cheef (pada bagian F\&B hotel dan Restoran), pembina OSIS, pembimbing life skill di sekolah, sebagai ketua MGMP Bidang Studi Keterampilan, dan bahkan sudah ada yang menduduki sebagai kepala sekolah di SMK. Sebagai IT manager untuk Jurusan Manajemen Informatika, sebagai pengawas lapangan di PLN, dan kekapal bagian pengadaan bahan untuk Jurusan Teknik Elektronika, ketua MGMP TIK, kepala laboratorium untuk Jurusan PTI.

\subsection{Masa Tunggu Lulusan dalam Memperoleh Pekerjaan}

Hasil pengumpulan data terkait dengan masa tunggu lulusan dalam memperoleh pekerjaan menunjukan variasi yang cukup besar mulai dari masa tunggu yang kurang dari tiga bulan sampai dengan lebih dari satu tahun. Namun satu hal yang 
cukup menggembirakan dari 244 sampel yang mengembalikan kuisioner menunjukkan sebesar 134 orang $(54,92 \%)$ memberikan informasi tentang masa tunggu memperoleh pekerjaan. Sisanya sebesar $16.39 \%$, $18.44 \%$, dan $10.25 \%$ menyatakan memiliki masa tunggu antara 3-6 bulan, 6-12 bulan, dan lebih dari 12 bulan. Jadi rerata masa tunggu untuk memperoleh pekerjaan adalah 5.6 bulan untuk jurusan Pendidikan kesejahteraan Keluarga, 5.4 bulan untuk jurusan Manajemen informatika, 6.8 bulan untuk Jurusan Teknik elektronika, dan 3.3 bulan untuk Jurusan pendidikan Teknik Informatika.

\subsection{Mata Pelajaran yang Diampu (untuk Jurusan/Prodi S1 Kependidikan)}

Sesuai dengan bidanng pekerjaan alumni Jurusan Pendidikan Kesejahteraan Keluarga dan Pendidikan Teknik Informatika sebagai guru mata pelajaran di SMK, SMA, dan SMP menunjukkan sedikit bervariasi. Dari yang sangat sesuai dan sangat tidak sesuai dengan kompetensi. Seperti yang sangat btidak sesuai yang paling menonjol adalah sebagai guru yang mengampu mata pelajaran Budi pekerti dan PKn, terutama bagi alumni Jurusan Pendikan Kesejahteraan Keluarga.

Berikut ini disajikan tabel tentang variasi mata pelajaran yang diampu oleh para alumni Jurusan Pendidikan Kesejarteraan Keluarga dan Jurusan Pendidikan Teknik Informatika sebagai berikut (untuk jurusan dengan basis kependidikan).

Tabel 02. Mata Pelajaran yang Diampu Alumni di Sekolah

\begin{tabular}{|c|c|c|c|c|}
\hline $\mathrm{No}$ & Program Studi & Mata Pelajaran & $\mathrm{Jml}$ & Keterangan \\
\hline \multirow{5}{*}{1} & \multirow{5}{*}{ Tata Boga } & Produktif (Tata Boga) & 9 org & \\
\hline & & Tata Rias & 2 & \\
\hline & & Keterampilan & 6 & \\
\hline & & Budi Pekerti & 6 & \\
\hline & & Perhotelan & 4 & \\
\hline \multirow{4}{*}{2} & \multirow{4}{*}{ Tata Busana } & Produktif (Tata Busana) & 11 & \\
\hline & & Krya Tekstil & 4 & \\
\hline & & Keterampilan & 4 & \\
\hline & & Budi Pekerti & 1 & \\
\hline \multirow{4}{*}{3} & \multirow{4}{*}{ Pend. T. Informatika } & TKJ & 3 & \\
\hline & & TIK & 17 & \\
\hline & & Multi Media & 3 & \\
\hline & & Stop Motion Bidang & 1 & \\
\hline
\end{tabular}

JPTK, UNDIKSHA, Vol. 10, No. 1, Januari 2013 : 27 - 42 


\begin{tabular}{|l|l|l|l|}
\hline & Datar & & \\
\cline { 2 - 5 } & KKPI & 5 & \\
\cline { 2 - 5 } & Prog. Visual/Web & 2 & \\
\hline & Sistem digital & 1 & \\
\hline Sistem Operasi & 2 & \\
\hline & Sistem informasi & 1 & \\
\hline Metode Numerik & 1 & \\
\hline & $\begin{array}{l}\text { Rancang bangun WAN/ } \\
\text { Instalasi Perangkat } \\
\text { WAN }\end{array}$ & 2 & \\
\hline & $\begin{array}{l}\text { Desain Keamanan } \\
\text { Jaringan }\end{array}$ & 1 & \\
\hline $\begin{array}{l}\text { Ops. Server Dalam } \\
\text { jaringan }\end{array}$ & 1 & \\
\hline Matematika SMP & 1 & \\
\hline
\end{tabular}

\subsection{Variasi Jam Mengajar Untuk Jurusan Kependidikan di FTK}

Variasi jumlah jam mengajar guru dari alumni Jurusan Pendidikan Kesejarteraan Keluarga dan Jurusan Pendidikan Teknik Informatika diberbagai sekolah tempat bekerja menunjukkan kisaran rata-rata di atas 12 jam per minggu. hal ini menunjukkan bahwa para alumni FTK di sekolah tidak sampai kekurangan jam pelajaran dari aturan yang berlaku yaitu minimal 12 jam per minggu.

\subsection{Kompetensi Lulusan di Lapangan}

Kompetensi lulusan Fakultas Teknik dan Kejuruan di dunia kerja ditinjau dari delapan aspek yang diteliti menunjukkan penguasaan dalam katagori baik. Hal ini dibuktikan dengan rerata perolehan skor yang berkisar antara 3.25 sampai 4.44 dari skor terendah dan skor tertinggi yang mungkin dicapai yaitu 1 dan 5. Diantara perolehan skor tersebut secara rata-rata terdapat beberapa perolehan skor yang cukup ekstrim yang berkisar antara 1 dan 2, namun jumlahnya tidak begitu banyak, yaitu pada kompetensi bekerjasama dengan pihak lain dalam mengembangkan diri untuk melaksanakan tugas dalam bidang akademik, profesi, dan vokasional, dan kompetensi menguasai prinsip metodologi bidang kependidikan/ non kependidikan di bidang teknik dan kejuruan. Hal itu perlu dianalisis lebih lanjut keberadaanya. 


\subsection{Penilaian Alumni terhadap Administrasi dan Fasilitas Lembaga}

Hasil penilaian dan saran alumni terhadap administrasi dan fasilitas diperoleh gambaran dan saran sebagai berikut.

1) Bidang akademik. Diperoleh masukan berupa saran untuk terus berupya meningkatkan kualitas pembelajaran melalui peningkatan fasilitas dan media pembelajaran sesuai perkembangan IPTEKS. Sedangkan dari segi pelayanan akademik baik di jurusan maupun fakultas sudah cukup memadai.

2) Bidang kemahasiswaan. Dari segi kuantitas dan kualitas kegiatan bidang kemahasiswaan diperoleh masukan untuk lebih meningkatkan kegiatan yang bermanfaat untuk peningkatan kemampuan mahasiswa di bidang organisasi sehingga diperoleh peningkatan kemampuan mahasiswa untuk memahami realitas bermasyarakat setelah mereka bekerja maupun sebagai anggota masyarakat.

3) Bidang administrasi. Pelayanan administrasi baik di tingkat fakultas maupun di jurusan sudah tidak banyak disarankan oleh alumni, namun untuk memperlancar semua pelayanan di bidang administrasi akademik maupun administrasi kemahasiswaan perlu peningkatan dan penambahan fasilitas yang memadai.

4) Sedangkan hal lain yang diperoleh dari masukan dan saran alumni adalah pentingnya menjalin hubungan baik antara jurusan/fakultas/ universitas dengan para alumni dalam hal peningkatan kemampuan/ kompetensi para alumni melalui berbagai kegiatan pengabdian, loka karya, maupun studi lanjut.

\subsection{Kepuasan Pengguna Lulusan Terhadap Kompetensi yang Dimiliki Alumni}

Untuk lulusasn Manajemen Informatika dan Teknik Elektronika sebagai pengguna lulusannya adalah : perusahaan dan jasa di bidang teknologi informasi, Perusahaan listrik Negara (PLN), Perusahaan Telekomunikasi seperti PT Telkom, Indosat, Telkomsel, dll), dinas pendidikan, dan beberapa dinas di bawah depertemen keuangan, pertanian, hukum, staff sipil di kepolisian, staff sipil TNI, dan beberapa perusahaan swasta yang sesuaim dengan bidangnya. Namun untuk memperoleh 
gambaran tentang kepuasan pengguna penelitian ini hanya mendapatkan data dari pengguna lulusan yang ada di Provinsi Bali.

Gambaran tentang kepuasan pengguna lulusan FTK ini ditinjau dari delapan aspek yaitu : 1) kemampuan mengaktualisasikan diri sebagai anggota kelompok di lingkungan tempat tugas, 2) Tanggung jawab dalam melaksanakan tugas-tugas, 3) kemampuan mengembangkan profesionalitas dalam bidang pekerjaan, 4) keampuan bekerjasama dengan baik dengan teman sejawat, atasan dan bawahan, 5) kampuan menyesuaikan diri terhadap perubahan dalam perkembangan IPTEKS, 6) penguasaan konsep, pengetahuan, dan keterampilan di bidang pekerjaan, 7) kemampuan mengembangkan konsep bidang keilmuan dan keterampilan di tempat kerja, dan 8) keterampilan dalam mengaitkan konsep dan substansi keilmuan dan keterampilan dengan bidang pekerjaan.

Ditinjau dari kepuasan pengguna lulusan untuk semua jurusan menunjukkan bahwa semua pengguna lulusan FTK baik sebagai tenaga kependidikan (guru) dan non kependidikan secara umum menyatakan puas terhadap kompetensi yang dimiliki oleh lulusan FTK (100\% dari 42) pengguna lulusan yang diwawancarai dan diberikan kuisioner, terdapat beberapa butir/item pertanyaan yang diisi dengan tidak puas oleh pengguna lulusan, namun jumlahnya sangat kecil dan tidak berpengaruh secara signifikan. Namun hal ini perlu dianalisis dan ditelusuri lebih lanjut.

\subsection{Pembahasan}

Keterserapan alumni FTK tidak semuanya langsung bekerja menjadi guru atau sesuai dengan bidang atau spesialisasinya. Pekerjaan yang diperoleh setelah lulus sangat bervariasi, namun masih dalam konteks pekerjaan yang sesuai dengan kompetensinya sebagai lulusan pendidikan kejuruan. Hal ini menunjukkan bahwa disamping memiliki kompetensi sebagai guru kejuruan/ keterampilan(untuk program S1 Kependidikan), lulusan FTK juga memiliki kompetensi yang sesuai dengan bidang-bidang pekerjaan di dunia usaha dan industri yang berkembang. Berbeda halnya dengan lulusan D3, walaupun pekerjaan yang diperoleh setelah lulus sangat bervariasi, namun pekerjaan-pekerjaan tersebut memiliki kesesuian dengan bidang ilmu dan keterampilan yang diperoleh selama menjadi mahasiswa. Namun di 
satu sisi program studi/ Jurusan harus tetap menampung dan mencari informasi sebanyak-banyaknya tertkait dengan perkembangan industrti tertutama yang berhubungan dengan perubahan dan kemajuan IPTEKS. Hal ini perlu diperhatikan sebagai masukan yang penting dalam pengelolaan dan pengembangan kurikulum agar dapat disesuaikan dengan perkembangan dunia kerja. Akan tetapi sebagai tantangan kurikulum FTK hendaknya mengintegrasikan kompetensi yang terkait dengan kemampuan berkomunikasi, bekerjasama, negosiasi, dan beberapa keterampilan life skill lainnya ke dalam pembelajaran. Disamping itu kompetensi wiraswasta sangat dibutuhkan alumni agar tidak hanya tergantung untuk mencari pekerjaan di dunia kerja, akan tetapi bagaimana alumni dapat memiliki paradigma berpikir "lulus", ciptakan peluang kerja". Karena dari segi keterampilan (hard skill) sangat mendukung untuk dikembangkan.

Permasalahan lain yang muncul dari keterserapan para lulusan FTK yang sangat bervariasi sebelum mereka mendapatkan pekerjaan yang sesuai dengan kompetensi yang utama seperti sebagai guru honor, bekerja di bank, bekerja di perusahaan atau jasa yang bukan merupakan kompetensi utamanya juga dapat disebabkan karena keterbatasan kesempatan para lulusan untuk menjadi guru terutama untuk lulusan Pendidikan Kesejahteraan keluarga, terbatasnya jumlah mata pelajaran yang sesuai dengan kompetensinya di tingkat SMP maupun SMA, belum begitu banyak berkembangnya jumlah SMK di bidang tata boga, dan tata busana. Hal ini perlu mendapatkan perhatian yang lebih serius dari berbagai pihak terutama dengan adanya kebijakan pemerintah untuk merubah jumlah sekolah menengah umum (SMA) yang menjadi lebih kecil dibandingkan dengan jumlah sekolah kejuruan (SMK) dengan proporsi 70 ; 30 (Road Mapp PSMK 2015)

Dilihat dari penghasilan yang diperoleh untuk pertama kalinya bekerja terlihat sangat bervariasi, akan tetapi sangat mencolok perbedaannya antara alumni yang bekerja di dunia industri dengan yang bekerja sebagai guru honorer. Sebagai guru honor di beberapa sekolah mereka dihargai sangat kecil, akan tetapi sebagai karyawan di dunia industrti mereka menempati posisi yang sesuai kompetensinya dan diberi penghargaan yang cukup besar. 
Jabatan yang diperoleh juga bervariasi. Di dunia industri alumni menempati posisi yang cukup bagus, seperti kepala bagian, dan cheef untuk restoran dan hotel, serta di bidang kependidikan sudah ada yang menempati posisi kepala sekolah, wakil kepala sekolah, dll.

Berdasarkan analisis data yang dilakukan, rerata masa tunggu lulusan FTK (jurusan kependidikan dn non kependidikan) dalam memperoleh pekerjaan 3 sampai 6 bulan dan 54,92\%. (48.48\% pada tahun 2008) menunjukkan masa tunggu kurang dari tiga bulan. Sehingga masa tunggu untuk lulusan FTK (S1 Kependidikan dan D3 Non Kependidikan) dikatagorikan sangat baik. Beberapa hal yang berkontribusi terhadap hal ini ditenggarai oleh para alumni tidak terikat dan terbatas memiliki kesempatan hanya menjadi guru saja, namun peluang pekerjaan di bidang kejuruan di dunia usaha dan industri sangat terbuka bagi mereka, disamping keterampilan yang dimiliki sangat relevan dengan dunia usaha dan industri.

Lulusan FTK (S1 Kependidikan) di sekolah dilihat dari mata pelajaran yang diampu menunjukkan kesesuaian dengan kompetensi atau bidang studinya, seperti keterampilan (IRT) bidang tata boga, tata hidang, tata busana, tata rias, krya tekstil, dan berbagai mata pelajaran yang relevan di bidang boga dan busana. Akan tetapi cukup banyak juga alumni yang mengajar tidak sesuai bidangnya seperti mata pelajaran budi pekeri dan PKn. Denbgan adanya kenyataan seperti ini perlu dijadikan sebagai masukan terhadap pengembangan kurikulum agar mengemas atau mengintegrasikan beberapa materi yang relevan dengan tugasnya sebagai guru di sekolah, disamping keterampilan soft skill. Untuk jurusan D3 Non Kependidikan nampaknya tidak banyak masalah terkait dengan bidang pekerjaan yang diperoleh. Seluruh alumni telah memperoleh pekerjaan yang sangat sesuai, akan tetapi posisi mereka masih dalam level staf dan ada sedikit dari mereka di level pimpinan.

Jumlah jam mengajar alumni di sekolah sangat bervariasi sesuai dengan mata pelajaran yang diampu dan tempat dimana alumni mengajar. Perbedaan tersebut juga disesuaikan dengan kesesuaian mata pelajaran yang diampu dengan kompetensi alumni. Untuk mata pelajaran yang kurang sesuai dengan kompetensi alumni biasanya alumni memperoleh jam mengajar lebih sedikit. Rentang minimal jam mengajar alumni diketahui 14 jam per minggu dan maksimal 35 jam per minggu. 
Dengan demikian secara keseluruhan dapat disimpulkan jumlah jam mengajar para alumni di sekolah tempat mereka bertugas sudah memenuhi syarat minimal yaitu 24 jam tatap muka per minggu. Hal ini didasarkan atas Permendiknas No. 74 tahun 2008 tentang Guru.

Ada beberapa kompetensi yang perlu diperhatikan dan dijadikan masukan untuk penyempurnaan kurikulum ke depan yaitu pada kompetensi mahasiswa dalam hal berkomunikasi dengan Bahasa Inggris, pemanfaatan ICT, dan kompetensi dalam bidang penelitian terutama terkait dengan pengembangan keilmuan dan profesinya sebagai guru maupun sebagai tenaga prtofesional di dunia usaha dan indiustri.

Masih ada beberapa butir dari kuisioner kepuasan pengguna lulusan yang memperoleh tanggapan kurang puas dari pengguna. Butir-butir kuisioner dalam penilaian kepuasan pengguna yang mendapat nilai kurang puas dari pengguna kususnya terkait dengan : 1) kemampuan mengembangkan profesionalitas dalam bidang pekerjaan dan kemampuan menyesuaikan diri terhadap perubahan dalam perkembangan IPTEKS. Dari kenyataan tersebut, perlu adanya peninjauan kurikulum secara berkala dan berkelanjutan di jurusan maupun di fakultas dan peninjauan terhadap pelaksanaan pembelajaran yang berbasis pada pengembangan profesionalitas mahasiswa, serta mengacu pada pengembangan ipteks.

\section{PENUTUP}

Berdasarkan analisis yang telah dilakukan, dabat ditarik kesimpulan sebagai berikut. 1) Keterserapan lulusan Fakultas Teknik dan Kejuruan Undiksha di masyarakat/ dunia usaha dan industri ditinjau dari ketersebarannya di wilayah Bali dan sekitarnya tergolong baik yang dibuktikan dengan diterimanya alumni di berbagai bidang pekerjaan yang rerlevan dengan kompetensinya, walaupun untuk S1 Kependidikan masih belum diterima sebagai guru kejuruan maupun di sekolah menengah pertama sebagai guru keterampilan (untuk Jurusan Pendidikan Kesejahteraan Keluarga) berbeda halnya dengan alumni Jurusan Pendidikan Teknik Informatika sudah terserap 100 sebagai guru TI baik di SMK/SMA dan SMP sebagai guru honorer maupun guru PNS. Dilihat dari jabatan yang diperoleh selama bekerja tertmasuk cukup baik dengan suatu bukti sudah ada dari alumni yang 
menempati posisi kepala sekolah, wakil kepala sekolah, ketua MGMP, dan di luar bidang kependidikan ada yang sudah menjhadi kepala bagian, dan Cheef. Demikian juga darti segi penghargaan/ gaji pertama yang diperoleh tergolong cukup. 2) Ratarata masa tunggu para alumni untuk memperoleh pekerjaan Lulusan FTK (S1 Pendidikan Kesejahteraan Keluarga) tergolong pendek, yaitu antara 3 sampai 6 bulan. Di samping itu 54, 92\% alumni FTK memperoleh pekerjaan di bawah 3 bulan. 3) Mata Pelajaran apa yang diampu di sekolah cukup bervariasi sesuai dengan kompetensi yang dimiliki, akan tetapi ada sejumlah alumni yang mengajar di luar kompetensinya seperti mata pelajaran budi pekerti. 4) Jumlah jam mengajar alumni di sekolah tergolong cukup dengan rentang 14 jam per minggu sampai 35 jam per minggu. 5) Kompetensi lulusan tergolong baik (berkisar antara 3,25 sampai 4,44 dari skor maksimal 5). Akan tetapi ada sejumlah kompetensi yang perlu ditingkatkan adalah kompetensi berkomunikasi dengan bahasa inggris, kompetensi pemanfaatan ICT dalam pembelajaran, dan kompetensi dalam bidang penelitian terkait pengembangan ilmu dan keterampilan. 6) Penilaian/ kepuasan alumni terhadap administrasi dan fasilitas lembaga tergolong baik, namun ada sejumlah layanan dan fasilitas yang perlu ditingkatkan oleh lembaga seperti : layanan perpustakaan, kegiatan kemahasiswaan, dan layanan internet. 7) Penilaian/ kepuasan pengguna lulusan/stakeholders menyebutkan tanggapan puas terhadap terhadap kinerja/ kompetensi alumni FTK ( $0 \%$ menyatakan tidak puas, $100 \%$ menyatakan puas, dan $0 \%$ menyatakan sangat puas, dari 42 pengguna lulusan yang menjawab dan memberikan tanggapannya melalui kuisioner).

Berdasarkan hasil temuan terhadap penelusuran alumni, dapat dipakai sebagai saran atau masukan kepada pihak yang terkait yaitu : 1) Guna menilai dan mengetahui keberadaan alumni di lapangan dan sebagai bentuk pertanggungjawaban lembaga terhadap perkembangan alumni di dunia kerja hendaknya dilakukan penelusuran secara berkala dan berkesinambungan, 2) Guna mendapatkan data yang komprehenship tentang perkembangan alumni di lapangan, fakultas atau lembaga hendaknya mengupayakan menjalin hubungan yang tidak tertputus dengan alumni, salah satunya melalui media tatap muka/ temu alumni secara berkala dan melalui ICT, 3) Hasil temuan dan masukan yang diperoleh hendaknya digunakan sebagai 
bahan masukan untuk pengembangan lembaga, fakultas dan jurusan secara berkelanjutan, 4) Fakultas/ lembaga hendaknya menyediakan dana yang lebih guna mendapatkan hasil penelusuran yang lebih banyak dan komprehenship, 5) Jurusan dan Fakultas perlu memfasilitasi terjadinya peninjauan kurikulum secara berkala dan berkelanjutan sesuai dengan tuntutan perubahan Jaman/IPTEKS, serta berorientasi pada tuntutan dan masukan dari pengguna lulusan.

\section{DAFTAR PUSTAKA}

Boediono. 1997. Pendidikan dan Perubahan Sosial Ekonomi. Yogyakarta : Aditya Media.

Rosyada, Dede. 2004. Paradigma Pendidikan Demokratis. Jakarta : Prenada Media.

Sukamto.2001. Perubahan Karakteristik Dunia kerja dan Revitalisasi Pembelajaran dalam Kurikulum Pendidikan Kejuruan. Pidato Pengukuhan Guru Besar. Yogyakarta : Universitas Negeri Yogyakarta.

Sutarto,H. 1998. Sebuah Reformasi Untuk Pendidikan Kejuruan Menjelang 2020. Jurnal PTK. Yogyakarta : IKIP.

Kep. Mendiknas Nomor 232/U/2000 tentang Pedoman Penyusunan Kurikulum Pendidikan Tinggi dan Penilaian Hasil Belajar.

Kep. Mendiknas Nomor 045/U/2002 tentang Kurikulum Inti Pendidikan Tinggi

JPTK, UNDIKSHA, Vol. 10, No. 1, Januari 2013 : 27 - 42 